\title{
Geobotanical and Ecological-Physiological Characteristics of Some Medicinal Species of the Genus Inula L. under Conditions of Uzbekistan
}

\author{
Nurbek Yu Kuchkarov \\ National University of Uzbekistan (Mirzo Ulugbek), Tashkent, Uzbekistan \\ Email: guljon.duschanova@mail.ru
}

How to cite this paper: Kuchkarov, N.Y. (2019) Geobotanical and Ecological-Physiological Characteristics of Some Medicinal Species of the Genus Inula L. under Conditions of Uzbekistan. American Journal of Plant Sciences, 10, 1830-1838. https://doi.org/10.4236/ajps.2019.1010129

Received: September 10, 2019

Accepted: October 22, 2019

Published: October 25, 2019

Copyright $\odot 2019$ by author(s) and Scientific Research Publishing Inc. This work is licensed under the Creative Commons Attribution International License (CC BY 4.0).

http://creativecommons.org/licenses/by/4.0/

\begin{abstract}
The article presents the geobotanical and some bioecological features of species of the genus Inula L., family Asteraceae (Compositae). The water regime, as well as the water holding capacity, transpiration rate and adaptive ability of plants to drought in the arid zone, is considered. The results of studies on the introduction into the culture based on indicators of the osmotic pressure of cell juice are presented.
\end{abstract}

\section{Keywords}

Inula helenium L, Inula salicina L, Ecological, Physiological, Water Regime, Ontogenesis, Seed, Uzbekistan

\section{Introduction}

The Asteraceae family is one of the largest families of dicotyledonous plants, which number from 1150 to 1300 genera and more than 20,000 species in the world. Asteraceae has a large range of plants spread from the tundra to the equator, on the shores of the sea to snow in the alpine region, on sands, on lands with black soils [1]. The genus Inula L. has about 100 species. They are widespread in Eurasia (from the Canary Islands to Japan), as well as in Africa and on the islands of Madakascar. In the CIS countries, 32 species are found. In particular, 9 species grow in Uzbekistan: Inula helenium, Inula grandis Schrenk., Inula salicina, Inula glauca C., Inula caspica Blume., Inula britannica L., Inula macrolepis Bunge., Inula rhizocephala Schrenk., Inula multicaulis Karel [2] [3]. 
Inula helenium is distributed in the European part of Russia (central and southern regions), Western Siberia (the north of the Altai-Sayan mountain country), Europe, South Asia, the Mediterranean, the Caucasus and Central Asia (Figure 1).

The root of the Inula helenium plant is used in medicine for the treatment of respiratory diseases. Inula helenium root preparations have the ability to prevent respiratory diseases, inflammation and reduce the secretion of intestinal function, and are also very effective in the treatment of gastrointestinal diseases [4].

The leaves and roots of the Inulahelenium plant contain essential oils (1\% $3 \%)$, saponins, resins, mucus and bitters. The main ingredient in the root is alantolactone, a mixture of essential oil isoalantolactone. Their mixture was formerly called gelenin. In addition, the roots of digidroalantolactone, fridelin, dammaradienylacetate, dammaradienol, phytomelane and other acetylene compounds, as well as stigmasterine, inulin, and pseuddoinulin have been isolated from the roots [5] [6].

The underlying organs of the Inula helenium plant contain essential oils, bitter and mucous substances, saponins, resins, inulin, alkaloid scars, vitamin E and gum. Tincture of the root of this plant is used in the treatment of respiratory diseases: bronchitis, tracheitis, pulmonary tuberculosis. In addition, the preparations of the Inula helenium plant can cure gastrointestinal diseases [7].

The aim of the research work is to develop a method for introducing promising medicinal plants into the culture of Inula helenium L.-Elecampane high and Inula salicina L.-Elecampane.

\section{Materials and Methods}

Ways to determine the ability of plants to adapt to drought and climate change conditions have been studied on the basis of bioecological and ecological-physiological characteristics. Research work was carried out from 2017 to 2018 in the north-western hilly part of the territory of the Botanical Garden of the National University of Uzbekistan, the geographical coordinate of the study site at an altitude of $442 \mathrm{~m}$ above sea level (m. 41 $20^{\prime} 55.60^{\prime \prime}$ Lat, 69 $12^{\circ} 03.43^{\prime \prime}$ Long). The soil is a typical gray earth; the climate is sharply continental, daily and seasonal indicators meteorological conditions have a dramatically changing feature. To study the seasonal development of plants, the methods of I. N. Beideman [8] and I. V. Borisov [9] were used.

The water content was determined using the gravitational method, the water holding capacity in assimilation organs according to A. A. Nichiparovich [10], the osmotic pressure of cell juice according to N. A. Gusev [11] and soil moisture according to the method of T. T. Rakhimova [12].

According to Uzhydromet (Tashkent meteorological station), for the period 2017-2018, rainfall totaled 405.6 - $395.4 \mathrm{~mm}$ /year. Mostly, precipitation fell in January, February, March, April, May, December, and from June a decrease in precipitation was observed. The arid period lasted until late autumn. 


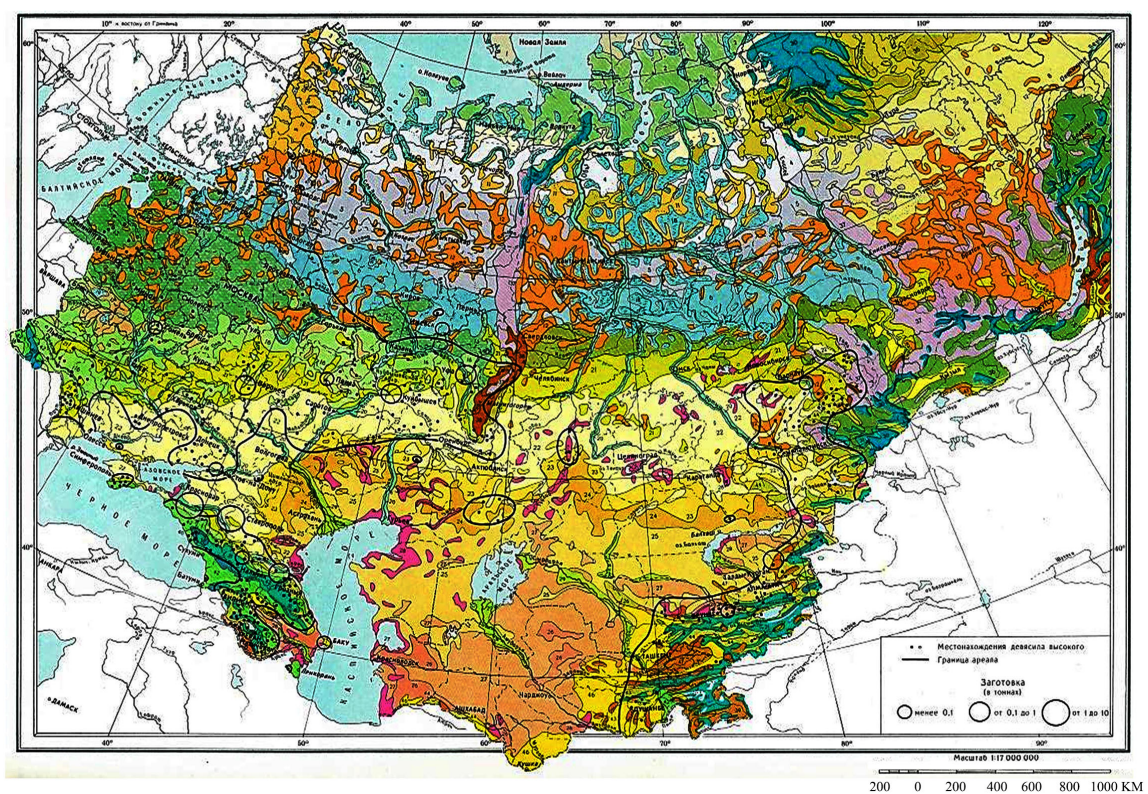

Figure 1. Areal Inula helenium L.

\section{Results and Discussion}

The following changes were observed during 2017: the average air temperature in January was $+2.5^{\circ} \mathrm{C}-7.1^{\circ} \mathrm{C}$. From June to August, the temperature was noted, respectively $+27.2^{\circ} \mathrm{C}-26.7^{\circ} \mathrm{C}$. The average annual air temperature was $+16^{\circ} \mathrm{C}$, the average annual relative humidity was $52 \%$. The average air temperature reached $+2.5^{\circ} \mathrm{C}-6.1^{\circ} \mathrm{C}$ in January 2018 and $+29^{\circ} \mathrm{C}-31.3^{\circ} \mathrm{C}$ in July. The average annual air temperature was $+16.4^{\circ} \mathrm{C}$ and the average annual relative humidity was $48.7 \%$. During the years of observation, hot days lasted from the third decade of May to the end of September. This period is characterized by an increase in temperature during the day and evening and was also characterized by hot and dry weather (Figure 2).

Observations showed that soil moisture varies over a year in layers of up to 50 $\mathrm{cm}$ (Table 1). The change in soil moisture at the experimental site in 2017 averaged in April - May, $15.1 \%$ - 14.5\%. In the dry period, from June to September, fluctuations were observed-12.4\%, 11.8\%, 10.4\%, 11.4\%. In 2018, changes were recorded in April on average 14.9\%, in May-13.2\%, in the driest period from June to September, the humidity was $12.4 \%, 11.8 \%, 10.4 \%, 11.4 \%$.

The seeds of Inula helenium sown in early spring at the experimental site began to germinate from the third decade of March 2017. In the first growing year, plants underwent growth, juvenile, immature, and virginal periods of growth and development. By the second year (2018), Inula helenium began to multiply from the second decade of March; in the second decade of May, the budding phase began. Since the second decade of June, the flowering phase has passed. Seed formation began in the 2nd decade of July and continued until seed maturation, i.e. September-October. In the year of vegetation, the growth of elecampane was $175 \mathrm{~cm}$. 


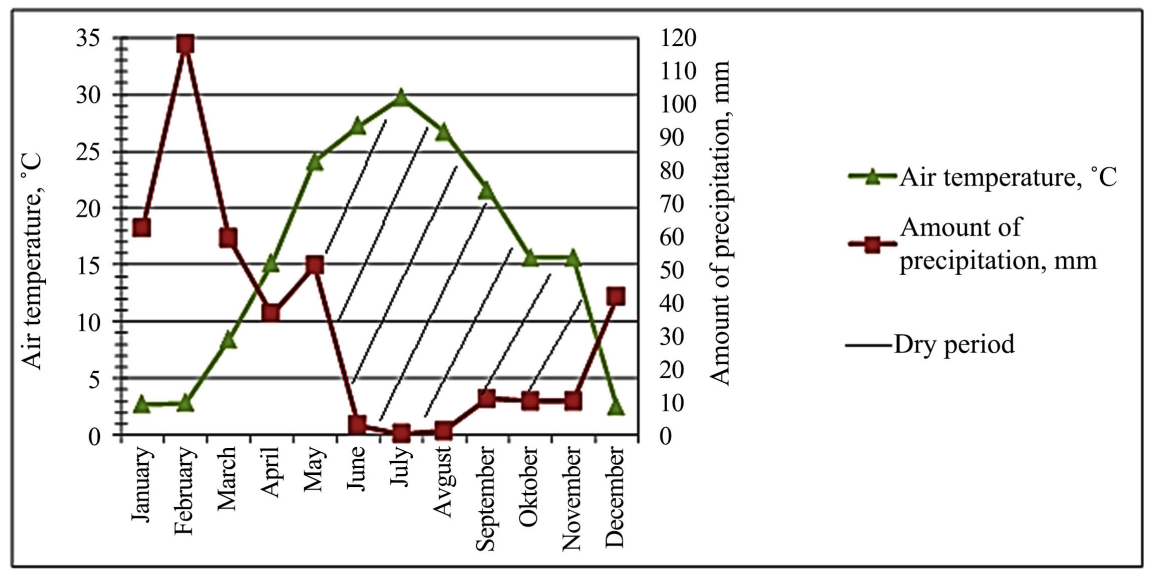

(a)

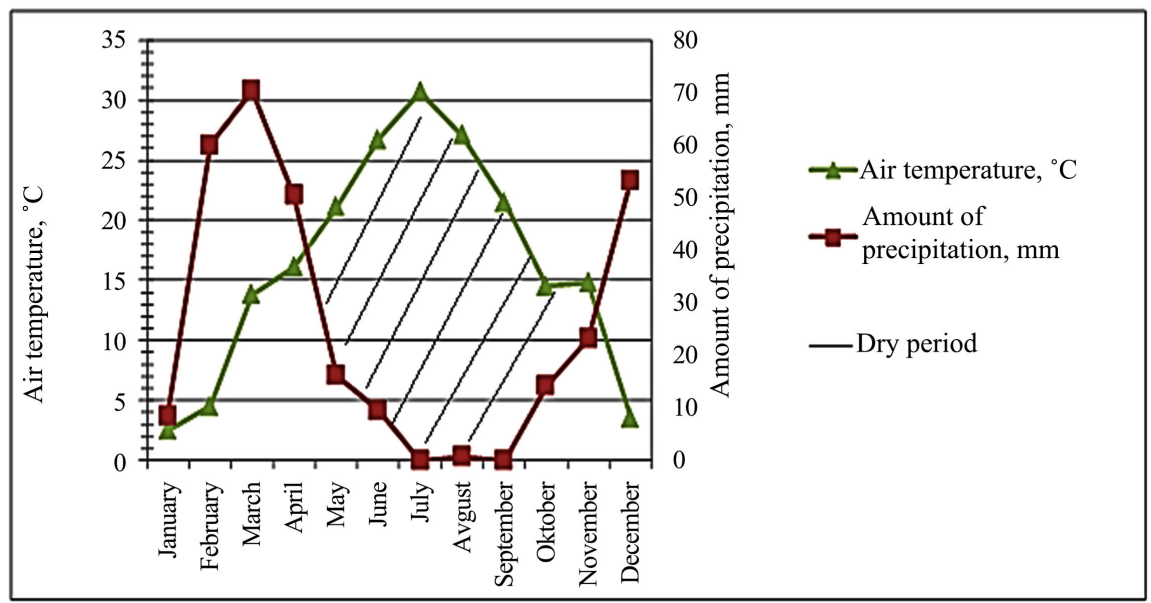

(b)

Figure 2. Climatic diagram: (a) -2017; (b) -2018.

Table 1. The change in soil moisture in the experimental plot (in\%).

\begin{tabular}{|c|c|c|c|c|c|c|c|}
\hline \multirow{2}{*}{ Years } & \multirow{2}{*}{ Soil layers (cm) } & \multicolumn{6}{|c|}{ Months of observation } \\
\hline & & April & May & June & July & August & September \\
\hline \multirow{6}{*}{2017} & $0-10$ & 12.3 & 10.5 & 8.0 & 10.5 & 10.8 & 11.2 \\
\hline & $10-20$ & 14.7 & 13.7 & 9.5 & 11.0 & 11.5 & 12.0 \\
\hline & $20-30$ & 15.9 & 14.7 & 12.2 & 11.8 & 12.0 & 14.8 \\
\hline & $30-40$ & 16.0 & 16.0 & 12.4 & 12.5 & 13.0 & 16.0 \\
\hline & $40-50$ & 16.7 & 17.8 & 13.2 & 13.8 & 13.9 & 16.2 \\
\hline & Average & 15.1 & 14.5 & 11.0 & 11.9 & 12.2 & 14.0 \\
\hline \multirow{6}{*}{2018} & $0-10$ & 14.0 & 12.0 & 11.0 & 10.2 & 7.7 & 10.0 \\
\hline & $10-20$ & 14.5 & 12.8 & 11.5 & 11.0 & 8.9 & 10.3 \\
\hline & $20-30$ & 15.2 & 13.4 & 12.6 & 12.2 & 9.8 & 11.5 \\
\hline & $30-40$ & 15.3 & 13.5 & 13.0 & 12.8 & 12.2 & 12.0 \\
\hline & $40-50$ & 15.7 & 14.5 & 14.2 & 13.1 & 13.6 & 13.6 \\
\hline & Average & 14.9 & 13.2 & 12.4 & 11.8 & 10.4 & 11.4 \\
\hline
\end{tabular}


In 2017, Inula salicina began to breed in the first year of vegetation, starting from the third decade of March. Since the first ten days of June, the budding phase has passed. From the first ten days of July, the flowering phase was noted, and seed formation began in the first ten days of August and continued until the seeds ripened in September-October. Plants underwent growth, juvenile, immature, virgin and generative periods of ontogenesis.

In the second growing season of 2018, Inula salicina began to breed from the first decade of March. Starting from the third decade of May, the budding phase took place, from the third decade of June they went into the flowering phase, seed formation began in the 3rd decade of July and continued until the seed ripened in September-October. The growth of Inula salicina reached $70 \mathrm{~cm}$; vegetation continued until late autumn (Figure 3).

During the season, the vegetative development of plants coincided with the dry period, therefore, the ability of species to the ecophysiological adaptation to these conditions was determined on the basis of studying the water regime. During the years of observation, various indicators of the water regime of plants, including the water-holding ability in assimilating organs, the transpiration rate, and the osmotic pressure of the cell sap were determined using scientifically based methods. The results of the study are shown during the season (Table 2).

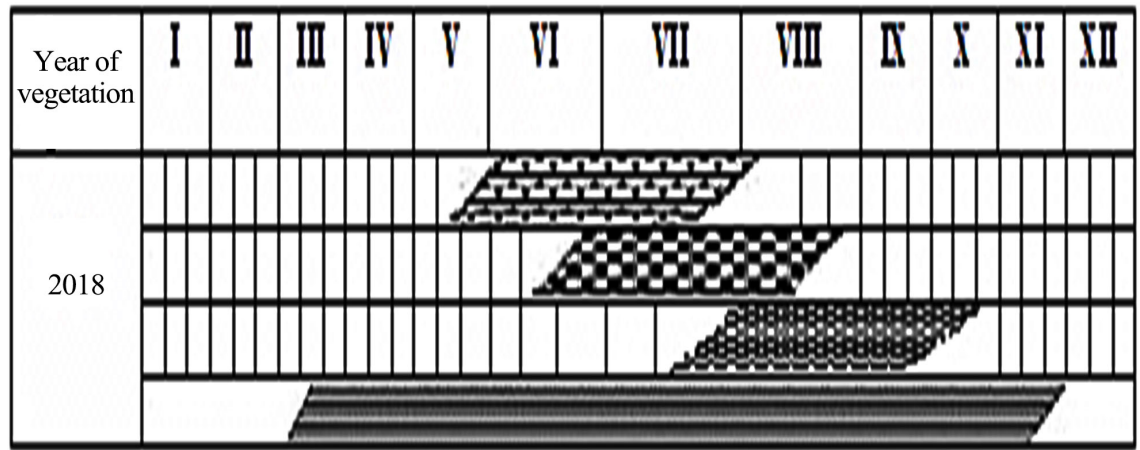

(a)

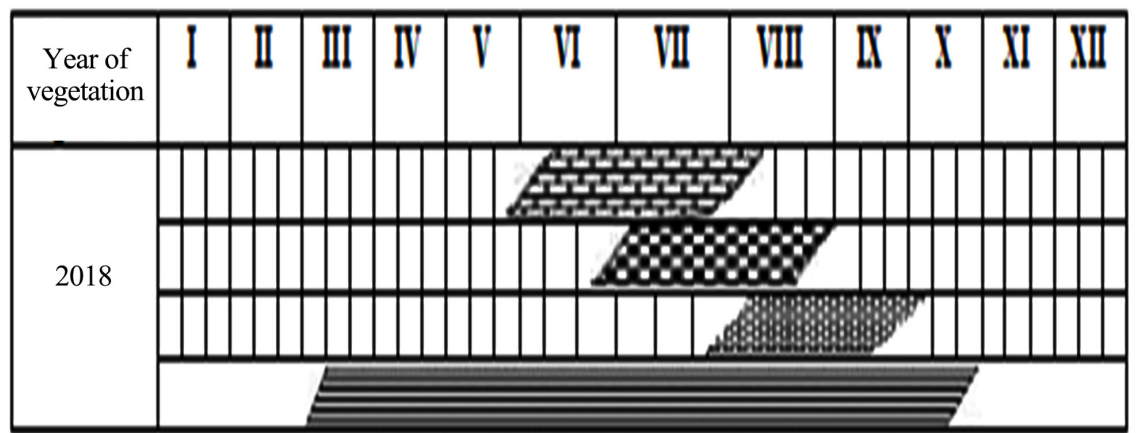

(b)
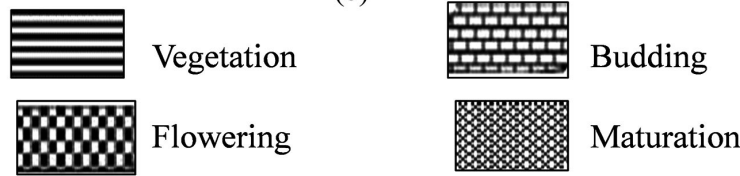

Figure 3. Phenospectrum Inula helenium (a) and Inula salicina (b). 
Table 2. The water regime of the species Inula helenium L and Inula salicina L (2017-2018).

\begin{tabular}{|c|c|c|c|c|c|c|}
\hline Year & Month & Name of plants & $\begin{array}{c}\text { Water retention } \\
\text { capacity, \% }\end{array}$ & $\begin{array}{c}\text { Water } \\
\text { content, \% }\end{array}$ & $\begin{array}{c}\text { The } \\
\text { transpiration } \\
\text { rate } \mathrm{mg} / \mathrm{g} / \mathrm{h} \text {. }\end{array}$ & $\begin{array}{c}\text { Osmotic } \\
\text { pressure, atm. }\end{array}$ \\
\hline \multirow{12}{*}{2017} & \multirow{2}{*}{ IV } & I. helenium & 77.4 & 85.3 & 1297 & 19 \\
\hline & & I. salicina & 75.6 & 85.7 & 1080 & 17 \\
\hline & \multirow{2}{*}{ V } & I. helenium & 74.2 & 84.7 & 1609 & 23 \\
\hline & & I. salicina & 73.4 & 85.4 & 2237 & 22 \\
\hline & \multirow{2}{*}{ VI } & I. helenium & 70.3 & 76.4 & 2044 & 24 \\
\hline & & I. salicina & 69.0 & 82.0 & 2423 & 23 \\
\hline & \multirow{2}{*}{ VII } & I. helenium & 67.5 & 74.9 & 2237 & 26 \\
\hline & & I. salicina & 66.5 & 80.8 & 2445 & 25 \\
\hline & \multirow{2}{*}{ VIII } & I. helenium & 69.4 & 74.5 & 2261 & 28 \\
\hline & & I. salicina & 65.4 & 76.4 & 2352 & 27 \\
\hline & \multirow{2}{*}{ IX } & I. helenium & 69.1 & 72.2 & 1211 & 24 \\
\hline & & I. salicina & 59.4 & 75.6 & 1724 & 22 \\
\hline \multirow{12}{*}{2018} & \multirow{2}{*}{ IV } & I. helenium & 80.4 & 85.8 & 1277 & 18 \\
\hline & & I. salicina & 78.0 & 86.2 & 1151 & 17 \\
\hline & \multirow{2}{*}{ V } & I. helenium & 72.0 & 81.7 & 1633 & 22 \\
\hline & & I. salicina & 70.2 & 84.8 & 2236 & 23 \\
\hline & \multirow{2}{*}{ VI } & I. helenium & 71.3 & 76.4 & 2044 & 24 \\
\hline & & I. salicina & 69.4 & 84.2 & 2387 & 25 \\
\hline & \multirow{2}{*}{ VII } & I. helenium & 70.2 & 74.7 & 2279 & 26 \\
\hline & & I. salicina & 64.5 & 78.1 & 2428 & 26 \\
\hline & \multirow{2}{*}{ VIII } & I. helenium & 69.3 & 73.8 & 2326 & 28 \\
\hline & & I. salicina & 58.4 & 75.2 & 2302 & 26 \\
\hline & \multirow{2}{*}{ IX } & I. helenium & 67.2 & 67.1 & 1271 & 24 \\
\hline & & I. salicina & 54.2 & 69.5 & 1627 & 24 \\
\hline
\end{tabular}

The water holding capacity of Inula helenium in the first year of the growing season was $77.4 \%$ in April, $74.2 \%$ in May, $70.3 \%$ in June, $67.5 \%$ in July, and 69.4\% in August, in September-69.1\%. In the second growing season, data were recorded in April-80.4\%, in May-72\%, in June-71.3\%, in July-70.2\%, in August $-69.3 \%$, in September-67, 2\%. During the first year of vegetation, the water-holding capacity in the leaves of Inula helenium plants was $9.9 \%$ of the range of seasonal changes, and in the second year, this range was $13.2 \%$.

The water holding capacity of Inula salicina during the first growing season was $75.6 \%$ in April, $73.4 \%$ in May, 69\%, 66.5\% and 65.4\% during the summer, respectively, for 3 months, in September $-59.4 \%$. In the second year of vegetation in April, the water holding capacity of Inula salicina was $78 \%$, in 
May-70.2\%, in June-69.4\%, in July-64.5\%, in August-58.4\%, in September-54.2\%. While the seasonal variation in the water holding capacity of Inula salicina L. in the leaves was $16.2 \%$ in the first year, this indicator in the second growing year was $23.8 \%$.

Throughout the season, a decrease in the water holding capacity of plants with the onset of the dry period was observed.

During the season, the average daily increase in water content in the assimilation organs of plants during the growing season of the first year was $85.3 \%$ in Inula helenium in April, with the beginning of the dry period from May to September, respectively: $84.7 \%, 76.7 \%, 74.9 \%, 74.5 \%$ and $72.2 \%$. The following changes were observed during the growing season of the second year: in April-85.8\%, with the beginning of the dry period in May-81.7\%, in the summer in June-76.7\%, in July-74.7\%, in August-73.8\% and in the first month of autumn-61.7\%. While the amount of water in Inula helenium varies during the day, its maximum amount is reached during the growing season of the first year in April-85.3\%, the minimum-in September-72.2\%, seasonal amplitude-13.1\%. In the second year of the growing season, the maximum in April was $85.8 \%$, the minimum in September was $61.7 \%$, and the seasonal amplitude was $18.7 \%$.

In Inula salicina, there was a change in the water content in the assimilation organs during the growing season of the first year, and the average daily values were $85.7 \%$ in April and $85.4 \%$ in May. In the summer dry period, these indicators were $82.0 \%$ in June, $80.8 \%$ in July, $76.4 \%$ in August, and $75.6 \%$ in the first month of autumn. During the growing season of the second year, the water content in foliage in April was 86.2\%, in May-84.8\%, in June-84.2\%, in July-78.1\%, in August-75.2\%, in September-69.5\%. While the water content in Inula salicina changed during the day, its maximum amount reached $85.7 \%$ during the first year of the growing season in April, the minimum in September-75.6\%, and the seasonal amplitude-10.1\% In the second year of the growing season, the maximum water content in April was 86.2\%, the minimum in September was $69.5 \%$ and the seasonal amplitude was $16.7 \%$. Thus, during the season, a decrease in the water content from spring to summer months was observed in the assimilation organs of plants. Throughout the season, the water content mainly reached high levels at the beginning of the day and decreased by the end of the day.

The transpiration rate in Inula helenium in the growing season of the first year in April was 1297 mg/g hour in May-1609 mg/g hour, in June-2044 mg/g hour, in July-2237 mg/g hour, in August-2261 mg/g hour, in September- $1211 \mathrm{mg} / \mathrm{g}$ hour. In the second year, this indicator in April was $1281 \mathrm{mg} / \mathrm{g}$ hour, in May-1633 mg/g hour, in June-2040 mg/g hour, in July-2279 mg/g hour, in August-2326 mg/g hour, in September-1267 mg/g hour. It was determined that the transpiration rate in Inula helenium during the first year averaged $1776 \mathrm{mg} / \mathrm{g}$ hour, in the second year- $1804.3 \mathrm{mg} / \mathrm{g}$ hour. 
The transpiration rate in Inula salicina during the growing season of the first year was on average $1082 \mathrm{mg} / \mathrm{g}$ hour in April, $2237 \mathrm{mg} / \mathrm{g}$ hour in May, 2423 $\mathrm{mg} / \mathrm{g}$ hour in June, $2445 \mathrm{mg} / \mathrm{g}$ hour in July, in August-2352 mg/g hour, in September- $1724 \mathrm{mg} / \mathrm{g}$ hour. In the growing season of the second year, the transpiration rate of Inula salicina in April was $1151 \mathrm{mg} / \mathrm{g}$ hour, in May-2236 mg/g hour, in June-2387 mg/g hour, in July-2428 mg/g hour, in August-2302 $\mathrm{mg} / \mathrm{g}$ hour; in September- $1627 \mathrm{mg} / \mathrm{g}$ hour. It was noted that the average seasonal transpiration rate in Inula salicina in the first growing year was 2043.8 $\mathrm{mg} / \mathrm{g}$ per hour and in the second growing year $2021.8 \mathrm{mg} / \mathrm{g}$ per hour. This is due to global warming.

In a comparative analysis of both plants, it was noted that the transpiration rate in Inula salicina is higher than in Inula helenium.

Thus, with the beginning of the dry period from June to August, the maximum increase in transpiration intensity was found in both plant species. At the end of the season, with a decrease in illumination, a decrease in air and soil temperature, the intensity of transpiration decreased. During the experiments, it was found that the change in transpiration intensity is also associated with the growth and development of plants throughout the season.

\section{Conclusion}

The water-holding capacity, transpiration rate, and osmotic pressure of cell juice in the assimilation organs of Inula helenium change throughout the season depending on temperature, relative humidity, and rainfall. It was established that an increase in the osmotic pressure of plants throughout the season is the main indicator of the adaptation of these species to drought conditions. According to the adaptation properties, these plants were included in the group of xeromesophytes such as mesophytes. In 2018, the water holding capacity of Inula salicina was in the range of $23.8 \%$, which is $10.6 \%$ higher than in Inula helenium. Good growth rates, periods of budding, flowering and maturation of Inula helenium and Inula salicina were determined in the hilly terrain of the Tashkent. Ecological and physiological characteristics of plants allow us to conclude that these plant species can adapt to various environmental conditions.

\section{Conflicts of Interest}

The author declares no conflicts of interest regarding the publication of this paper.

\section{References}

[1] Takhtadzhyan, A.P. (1981) Genus Inula L. Plant Life. Enlightenment, Moscow, Vol. 5, 510. (In Russian)

[2] Mayevsky, P.F. (2006) Flora of the Middle Zone of the European Part of Russia. Moscow, Vol. 10, 600. (In Russian)

[3] Nabiev, M.M. (1962) Genus Inula L. Flora of Uzbekistan, 6, 82-85. (In Russian)

[4] Tsitsin, N.V. (1962) Atlas of Medicinal Plants of the USSR. Publishing House of 
Honey, Moscow, 711. (In Russian)

[5] Sklyarevsky, L.Ya. and Gubanov, I.A. (1968) Medicinal Plants in Everyday Life. Rosselkhozizdat, Moscow, 224. (In Russian)

[6] Yanitskaya, A.V. and Mitrofanova, I.Yu. (2012) Elecampane High-A Promising Source of New Drugs. Bulletin of Volgograd State Medical University, S43, 24-27. (In Russian)

[7] Alimbaev, P., Nuralieva, J. and Arbaeva, E. (1990) Medicinal Plants of Kyrgyzstan. Mektep, 128. (In Russian)

[8] Beideman, I.N. (1974) Methodology for Studying the Phenology of Plants and Plant Communities: Novosibirsk. 154. (In Russian)

[9] Borisova, I.V. (1972) Seasonal Dynamics of the Plant Community. In: Field Geobotany, Nauka, Leningrad, Vol. 4, 5-94. (In Russian)

[10] Nichiporovich, A.A. (1926) About Water Loss by Cut off Parts of Plants during Wilting. Journal of Experimental Agronomy South-East, 3, 76-92. (In Russian)

[11] Gusev, N.A. (1960) Some Methods of Studying the Water Regime of Plants. Publishing House of the USSR Academy of Sciences, Leningrad, 61. (In Russian)

[12] Rakhimova, T.T. (2009) Plant Ecology and the Toolkit for the Discipline Phytocenology. Tashkent, 70. (In Russian) 